\section{Contemplation: When Enough is Enough}

Received: June 29, 2017; Accepted: July 14, 2017; Published: July 21, 2017

\section{Awad Magbri* and Eussera El-Magbri}

Dialysis Access Center of Pittsburgh, PA, USA

\author{
*Corresponding author: Awad Magbri \\ elmagbri@hotmail.com \\ Dialysis Access Center of Pittsburgh, PA, \\ USA.
}

Tel: +14122715106

Citation: Magbri A, El-Magbri E (2017)

Contemplation: When Enough is Enough. Acta Psychopathol. Vol. 3 No. 4:45

medical services are steps need to be taken [9-11]. We as doctors undertake decisions every day on the premises of defensive medicine. But, my question is, Why do we inflict trauma, pain, and suffering on our patients who do not ask for it, only to satisfy our complicated high-achieving egos that we did "something" to our patients and their families? What happened to the dictum "First, do no harm". The very same moral principles of medical mankind that brought us here [12]. Why are we overestimating our capacity to heal? The fact is changes have occurred in our health care over the last half-century, and therefore we must evolve and adapt those changes which benefit us all. It is our responsibility to go forth and educate our new generation of physicians on the harms they might inadvertently inflect by over treating the inevitable. We, as health care providers, must know when to stop futile measures, and contest drastic measures because they are not good choice for our patients. The consequences of overtreatment may do more harm than good. The United States does have a comparatively high level of imaging units and patient surgeries than other industrialized nations $[13,14]$. Government regulations are known to be effective strategy to control health care spending and curtail useless measures [15-17].

Furthermore, the lack of effective counseling to our patients feeds into the health care costs related to repercussions from undisciplined lifestyle choices such as smoking, drinking, unhealthy eating habits, overuse of drugs (prescription and nonprescription), in addition to partially unmasked patient safety concerns such as domestic and community violence, reckless driving, etc. [17]. The best-practice guidelines based on scientific 
medical evidence can help cut unjustifiable costs by avoiding care not based on demonstrable, value-added, cost-effective principles. This will challenge the existing, traditional art of medicine and may limit the endless increase in health care. It will certainly stimulate our thorough broad-based input and decisionmaking skills.

\section{References}

1 Evans RG (2008) Devil take hindmost: private health insurance and rising costs of American exceptionalism. In: Morone JA, Litman TJ, Robins LS (eds.) Health politics and policy ( $4^{\text {th }}$ edn.) Clifton Park (NY): Delmar Cengage Learning, pp: 445-474.

2 Anderson GF, Frogner BK (2008) Health spending in OECD countries: obtaining value per dollar. Health Aff (Millwood) 27: 1718-1727.

3 http://www.ovid.com/site/catalog/books/3229.jsp

4 Anderson OW (1968) Health services in a land of plenty. In: Edward WR (ed.) Environment and policy: The next fifty years, Indiana University Press, Bloomington, pp: 59-102.

5 Fuchs VR (1968) The growing demand for medical care. N Engl J Med 279: 190-195.

6 Anderson GF, Reinhardt UE, Hussey PS, Petrosyan V (2003) It's the prices, stupid: Why the United States is so different from other countries. Health Aff (Millwood) 22: 89-105.

7 Anderson GF, Hussey PS, Frogner BK, Waters HR (2005) Health spending in the United States and the rest of industrialized world. Health Aff (Millwood) 24: 903-914.
In conclusion, it is you and me who are going to emotionally and financially pay for this madness, not the insurance companies. Reasoning and rationalization for health care delivery has been a long part of humanity, however, it must be re-evaluated because the respect for human dignity, honesty, end of life decisions are what is going to save us from our self-destruction.

8 http//www.rwjf.org/files/research/101508.policysunthesis. costdrivers.rpt.pdf

9 Aaron HJ, Schwartz WB (1984) The painful prescription: rationing hospital care. Washington (DC): Brookings Institution.

10 Somers A (1971) The rationalization of health services: A universal priority. Inquiry 8: 48-60.

11 Mushkin SJ (1962) Health as an investment. J Polit Econ 70: 129-157.

12 Freidson E (1971) Profession of Medicine. New York: Dodd, Mead and Company.

13 Vladeck BC (2004) Everything new is old again. Health Aff (Millwood) 23: VAR-III.

$14 \mathrm{http} / / \mathrm{www} . \mathrm{mckinsey} . \mathrm{com} / \mathrm{mgi} / \mathrm{rp} /$ healthcare/accounting_cost_ healthcare.asp

15 http/www.kff.org/kaiserpolls/upload/7572.pdf

$16 \mathrm{http} / / \mathrm{www}$.ourfuture.org/healthcare/white

17 Morone JA (1992) The bias of American politics: rationing health care in a weak state. U Pa L Rev 150: 1923-1938. 